\title{
Water balance throughout the adult life span in a German population
}

\author{
Friedrich Manz ${ }^{1}$, Simone A. Johner ${ }^{1 *}$, Andreas Wentz ${ }^{2}$, Heiner Boeing ${ }^{3}$ and Thomas Remer ${ }^{1}$ \\ ${ }^{1}$ Research Institute of Child Nutrition, Rheinische Friedrich-Wilhelms University Bonn, Heinstueck 11, D-44225 Dortmund, \\ Germany \\ ${ }^{2}$ Hospital Düren, Paediatric Clinic, Roonstrasse 30, D-52351 Düren, Germany \\ ${ }^{3}$ German Institute of Human Nutrition (DifE), Potsdam-Rebbrücke, Arthur-Scheunert-Allee 114-116, D-14558 Nuthetal, \\ Germany \\ (Submitted 4 February 2011 - Final revision received 27 July 2011 - Accepted 27 July 2011 - First published online 16 September 2011)
}

\section{Abstract}

Mild dehydration, defined as a 1-2\% loss in body mass caused by fluid deficit, is associated with risks of functional impairments and chronic diseases. Whether water requirements change with increasing age remains unclear. Therefore, the aim of the present investigation is to quantify hydration status and its complex determining factors from young to old adulthood to analyse age-related alterations and to provide a reliable database for the derivation of dietary recommendations. Urine samples collected over a $24 \mathrm{~h}$ period and dietary records from 1528 German adults (18-88 years; sub-sample of the first National Food Consumption Survey) were used to calculate water intake (beverages, food and metabolic water) and water excretion parameters (non-renal water losses (NRWL), urine volume, obligatory urine volume) and to estimate hydration status (free-water-reserve) and 'adequate intake (AI)'. Median total water intake $(2483$ and $2054 \mathrm{ml} / \mathrm{d}$, for men and women, respectively $(P<0.0001)$ ), decreased with increasing age only in males $(P=0.001)$. Obligatory urine volume increased in both sexes $(P<0 \cdot 0001)$ due to decreased renal concentration capacity. The latter was balanced by a decrease of NRWL $(P<0 \cdot 05)$, leaving the free-water-reserve and therefore hydration status almost unchanged. Calculated 'AI' of total water was the same for young (18-24 years) and elderly ( $\geq 65$ years) adults (2910 and 2265 ml/d, for men and women, respectively). The present study is the first population-based examination showing that total water requirements do not change with age although ageing affects several parameters of water metabolism. Reduced sweat loss with increasing age appears to be primarily responsible for this observation.

\section{Key words: Hydration status: Elderly: Adequate water Intake: Urine osmolality}

Water constitutes approximately one-half of human body weight $^{(1)}$ and is essential for human life and health. Total body water is tightly regulated and there is increasing evidence that even mild dehydration (defined as a $1-2 \%$ loss in body mass caused by fluid deficit) may play a role in various morbidities like urolithiasis, constipation and hypertension ${ }^{(2)}$. Especially the elderly ( $\geq 65$ years) are at an increased risk of dehydration because they experience a decrease in thirst sensation and at the same time have an impaired capacity of their kidneys to concentrate the urine $\mathrm{e}^{(3-5)}$.

However, the scientific basis for water intake recommendations for the elderly is scarce and the recommendations from different nutrition societies are not consistent. The German Nutrition Society, for example, recommends a lower total water intake with increasing age ${ }^{(6)}$. In contrast, the US Institute of Medicine provides constant water intake recommendations (adequate intake (AI)) for younger and older adults. These AI values were based on the median total water intake of young adults to ensure an adequate amount of consumption in the elderly ${ }^{(7)}$. The European Food Safety Authority is trying to develop a European standard at present ${ }^{(8)}$. However, until now, detailed and representative data on water intake and hydration status of a population, which is the requirement to derive a reliable basis for intake recommendations, are missing.

Some years ago, we presented a concept of estimating individual 24 h hydration status ${ }^{(9)}$. It complies with the concept of Dietary Reference Intakes from the US Institute of Medicine ${ }^{(7)}$, i.e. that the AI of a nutrient is the observed or experimentally determined estimated intake at which the risk of inadequacy is very low - only $2-3 \%{ }^{(7)}$. The $24 \mathrm{~h}$ hydration status of a subject is inadequate if the $24 \mathrm{~h}$ urine osmolality is above the mean $(-2 \mathrm{SD})$ value of experimentally determined maximum urine osmolality (for the respective life-stage group) ${ }^{(10)}$. The difference between the $24 \mathrm{~h}$ urine volume and the obligatory urine volume (i.e. the hypothetic volume necessary to excrete

Abbreviations: AI, adequate intake; NRWL, non-renal water losses; VERA, Verbundstudie Ernährungserhebung und Risikofaktoren-Analytik.

*Corresponding author: S. A. Johner, fax + 492317115 81, email johner@fke-do.de 
the actual $24 \mathrm{~h}$ urine solutes) is called the free-water-reserve ${ }^{(9)}$ - measuring the individual $24 \mathrm{~h}$ euhydration (calculations in detail are described in the Methods section).

Free-water-reserve is determined by various parameters of water metabolism: beverages and food water intake, metabolic water, non-renal water losses (NRWL), urine volume and obligatory urine volume. It is widely known that nearly all of these parameters undergo changes with increasing age. Elderly people show lower sweat losses ${ }^{(11,12)}$, and therefore NRWL decreases; at the same time renal concentration capacity becomes impaired ${ }^{(10)}$, resulting in an increased obligatory urine volume.

The aim of the present investigation was to quantify hydration status and its complex determining factors from young to old adulthood to analyse possible age-related alterations and provide a reliable basis for the derivation of dietary recommendations. We used data from the public use file and new results from the analysis of stored urine samples from the Verbundstudie Ernährungserhebung und RisikofaktorenAnalytik (VERA) study population of the National Food Consumption Survey of Germany in $1986-8^{(13)}$.

\section{Methods}

Between 1986 and 1988, a representative sample of 24632 persons of the Federal Republic of Germany living in 11141 households took part in the first National Food Consumption Survey ${ }^{(14,15)}$, documenting and analysing nutrition behaviour and physical activity by $7 \mathrm{~d}$ records and personal interviews. From this population, a representative sub-sample of 2006 persons aged 18-88 years was taken randomly and $24 \mathrm{~h}$ urine samples were collected from each subject (Cooperative Study: Nutrition Survey and Risk Factors Analysis, VERA $)^{(15,16)}$. The original diet and health survey from which the information used in the present study was obtained had ethical approval from the commissioning Federal Ministry of Research and Technology, the Institutional Review Board of the Faculty of Nutritional Sciences, Justus-Liebig-University Giessen, Germany, and the Scientific Advisory Council of the VERA study. Urine collection, over a $24 \mathrm{~h}$ period, was carried out on one of the days of dietary recording; subjects were instructed by the interviewer how to perform $24 \mathrm{~h}$ urine collection. Completely collected frozen urine samples were directly transported to the laboratory for analysis. Remaining samples were stored at $<-80^{\circ} \mathrm{C}$. Urine osmolality was analysed (Osmometer OM 802-D; Vogel, Giessen, Germany) in the year 2003 from stored urine samples $\left(<-80^{\circ} \mathrm{C}\right)$. Stability of urine osmolality was previously checked by remeasurements of $24 \mathrm{~h}$ urine samples after 15 years of storage. Recovery rates of more than $95 \%$ ensured no disturbing effects of storage duration on urine osmolality. Measurements of $24 \mathrm{~h}$ urine osmolality were combined with previous measurements of urine volume and creatinine (Jaffé method) as well as data from the dietary record of the day of urine collection as available in the public use files of the VERA study ${ }^{(17)}$. In 115 subjects, single urine data were missing. In 269 subjects, the urine collection time was not in the range of 1200-1560 min. In ninety-one subjects, $24 \mathrm{~h}$ urine creatinine was below $0.1 \mathrm{mmol} / \mathrm{kg}$ per $\mathrm{d}$ in males and $0.09 \mathrm{mmol} / \mathrm{kg}$ per $\mathrm{d}$ in females ${ }^{(18)}$. In two subjects, $24 \mathrm{~h}$ urine volume was below $300 \mathrm{ml}$ and in one subject, body weight was missing. The final data sets included the data of 1528 subjects (women: $58.2 \%$; proportion of women in the initial VERA sample: $57.0 \%$; in the German population (1986-8, $\geq 20$ years): $52.7 \%$ ).

\section{Hydration status}

Total water intake corresponds to the sum of beverages, metabolic water and water in food (including milk and milk products) taken from the dietary record of the day of urine collection. All foods and beverages consumed were recorded, using food scales for weighing or standardised containers and templates to estimate the consumed amounts.

In water balance, total water intake corresponds to total water losses, which is the sum of NRWL and $24 \mathrm{~h}$ urine volume. Thus, NRWL correspond to the difference of calculated total water intake and measured $24 \mathrm{~h}$ urine volume:

$$
\begin{aligned}
\text { NRWL }(\text { litres } / \mathrm{d})= & \text { total water intake }(\text { litres } / \mathrm{d}) \\
& -24 \mathrm{~h} \text { urine volume }(\text { litres } / \mathrm{d}) .
\end{aligned}
$$

Renal solutes excretion $(\mathrm{mOsm} / \mathrm{d})$ corresponds to the product of urine osmolality $(\mathrm{mOsm} / \mathrm{kg}$ ) and $24 \mathrm{~h}$ urine volume (litres/d, assuming $1 \mathrm{~kg}$ water corresponds to 1 litre). Obligatory urine volume is defined as the water volume necessary to excrete $24 \mathrm{~h}$ urine solutes at the age-related lower limit of maximum urine osmolality (mean $(-2 \mathrm{SD})$ ). Based on literature data of standardised tests of renal concentration capacity in subjects in industrialised countries, the lower limit of maximum urine osmolality has been estimated to be 830 $\mathrm{mOsm} / \mathrm{kg}$ minus $3.4 \mathrm{mOsm} / \mathrm{kg}$ per year starting from an age of 20 years $^{(10)}$. The calculation of obligatory urine volume for an age above 20 years is:

Obligatory urine volume (litres/d)

$=24 \mathrm{~h}$ urine solutes $(\mathrm{mOsm} / \mathrm{d}) /(830-3.4 \times($ age -20$))$

(mOsm/1, assuming $1 \mathrm{~kg}$ water corresponds to 1 litre).

Free-water-reserve corresponds to the difference of the $24 \mathrm{~h}$ urine volume and the obligatory urine volume

Free-water-reserve (litres/d) $=24$ h urine volume $($ litres $/ \mathrm{d})$

$$
\text { - obligatory urine volume (litres/d). (3) }
$$

It quantifies individual $24 \mathrm{~h}$ hydration status ${ }^{(9)}$. If the value is positive, the subject is euhydrated. If it is negative (due to a $24 \mathrm{~h}$ urine osmolality above the mean $(-2 \mathrm{SD})$ value of maximum urine osmolality), the subject is hypohydrated or in a hydration status in the range at risk of hypohydration.

In a population, euhydration is ensured if at least $97 \%$ of the subjects show positive values of free-water-reserve ${ }^{(7)}$. 
Euhydration may be achieved in a population at risk of hypohydration by a general increase in the level of total water intake (the theoretically required increase is represented by the calculated 3rd percentile value of free-water-reserve). Thus, the AI of total water of a population is the sum of median total water intake minus the 3 rd percentile value of free-water-reserve ${ }^{(7,9)}$ :

Adequate total water intake (litres/d)

$=$ median total water intake $($ litres $/ \mathrm{d})$

- 3rd percentile of free-water-reserve (litres/d).

Another reasonable, less practicable concept to ensure euhydration is the reduction of obligatory urine volume (by the amount of the 3rd percentile volume of free-waterreserve) by a decrease of urine solutes excretion:

$$
\begin{aligned}
& \text { Decrease of urine solutes excretion }(\mathrm{mOsm} / \mathrm{d}) \\
& \begin{array}{r}
=3 \text { rd percentile free-water-reserve }(\text { litres } / \mathrm{d}) \\
\quad \times(830-3 \cdot 4(\text { age }-20))(\mathrm{mOsm} / \text { litres }) .
\end{array}
\end{aligned}
$$

The high NRWL in men can be divided into an energyrelated part (in accordance with the common approach of relating water intake recommendations to units of energy intake $\left.{ }^{(8,19)}\right)$ and a male-specific part, accounting for the generally higher NRWL in males than in females, even if the differences in energy intake are taken into account. The energyrelated part corresponds to the product of the age-groupspecific mean female NRWL and the corresponding ratio of mean male and female energy intakes:

$$
\begin{aligned}
\text { Energy-related NRWL }= & \text { mean NRWL (women }) \\
& \times(\text { mean energy intake }(\text { men }) / \\
& \text { mean energy intake (women) }) .
\end{aligned}
$$

Male-specific NRWL $=$ NRWL $($ men $)-$ energy-related NRWL.

\section{Statistical analysis}

Anthropometric data, energy intake and results of water balance are given as means and standard deviations, stratified by age groups of $18-24,25-49,50-64$ and $\geq 65$ years. These age ranges were selected according to the actual age categorisation of the German Nutrition Society ${ }^{(6)}$. Sex differences were tested by an unpaired $t$-test. To investigate the effects of age on the various parameters of water balance, a linear regression model was calculated for each parameter adjusted for energy intake and physical activity. Physical activity was defined as the sum of daily sports activities + cycling + moderate to vigorous physical activities (such as cleaning or gardening) and was expressed in hours. All regression models were run sex-stratified. Concerning free-water-reserve, the effects of the following factors were additionally included and tested for significance: education (four levels: elementary school, secondary school without diploma, diploma, academic studies), region ( $n$ 4: north, west, middle, south), size of place of residence (four categories: <2000, <20000, <500000, $\geq 500000$ inhabitants) and mean income per person of a household (five categories: <500, <1000, <1500, <2000, $\geq 2000$ D-Mark (approximately corresponding to $€$ today). To directly compare male and female parameters of water metabolism, differences of mean male and mean female parameters were calculated after adjusting the values of women to the energy intake of men (i.e. after multiplication of the female values with the age-group-specific ratio of mean male and female energy intakes). An effect was accepted as significant if the $P$ value (two-tailed) was below $0 \cdot 05$. All calculations were performed by using SAS procedures (version 8.02; SAS Institute, Cary, NC, USA).

\section{Results}

Anthropometric data, energy intake and results of the parameters of water balance of males and females from a formerly representative sample ( $n$ 1528) of the German population in 1986-8 aged 18-88 years (VERA study) are presented in Tables 1 and 2, respectively. Comparison between sexes showed a significance level of $P<0.0001$ for most of the presented parameters, except for urine solutes/energy $(P=0.0002)$ and urine volume $(P=0.49)$.

Median total water intake was $2483 \mathrm{ml} / \mathrm{d}$ in men and $2054 \mathrm{ml} / \mathrm{d}$ in women $(P<0 \cdot 0001)$. Free-water-reserve was negative in $40 \%$ of males and $19 \%$ of females. Euhydration would have been ensured in $97 \%$ of German adults, if the water balance had been improved by $427 \mathrm{ml} / \mathrm{d}$ in men and $211 \mathrm{ml} / \mathrm{d}$ in women by (a) an AI of total water of $2910 \mathrm{ml} / \mathrm{d}$ or $1.04 \mathrm{ml} / \mathrm{kcal}$ in men and $2265 \mathrm{ml} / \mathrm{d}$ or $1.05 \mathrm{ml} / \mathrm{kcal}$ in women, (b) a decrease of urine solutes excretion of $319 \mathrm{mOsm} / \mathrm{d}$ in men and $158 \mathrm{mOsm} / \mathrm{d}$ in women or (c) a mixture of both measures. Free-water-reserve was different in men and women $(P<0.0001)$. Education, region, size of place of residence, or income per person of a household (except in males, $P=0.03$ ) had no effect on free-water-reserve.

Several parameters of $24 \mathrm{~h}$ water metabolism were affected by age (Table 3 and Fig. 1). Urine osmolality decreased with age in both sexes (men $-3.0 \mathrm{mOsm} / \mathrm{kg}$ per year; women $-2.4 \mathrm{mOsm} / \mathrm{kg}$ per year, results from the linear regression of age on osmolality, adjusted for energy intake, and physical activity, Table 3). Total water intake remained constant with age in men $(P=0 \cdot 2)$; in women it increased $(P=0 \cdot 001)$. Comparing men (women) above 65 years with those $18-24$ years old, the proportion of beverages at $100 \%$ total water input decreased slightly by $4 \cdot 1 \%$ ( $5 \cdot 0 \%$; statistically not significant), whereas food water increased by $5.4 \%$ (7.3\%). The proportion of metabolic water decreased slightly with $-1.4 \%$ $(-2 \cdot 3 \%)$. The proportion of NRWL at $100 \%$ water output decreased by $22 \cdot 2 \%(10 \cdot 3 \%)$, whereas the proportion of obligatory urine volume increased by $18 \cdot 1 \%$ (10.9\%) and the proportion of free-water-reserve remained almost unchanged at $+4.0 \%(-0.4 \%)$. The excretion of urine solutes 
Table 1. Anthropometric data, energy intake and results of water balance of men from a formerly representative sample of the German population (VERA study)

(Mean values and standard deviations and medians)

\begin{tabular}{|c|c|c|c|c|c|c|c|c|c|c|}
\hline \multirow[b]{2}{*}{ Age (years) } & \multicolumn{2}{|c|}{$18-24$} & \multicolumn{2}{|c|}{$25-49$} & \multicolumn{2}{|c|}{$50-64$} & \multicolumn{2}{|c|}{$\geq 65$} & \multicolumn{2}{|c|}{ All } \\
\hline & Mean & SD & Mean & SD & Mean & SD & Mean & SD & Mean & SD \\
\hline$n$ & \multicolumn{2}{|c|}{79} & \multicolumn{2}{|c|}{308} & \multicolumn{2}{|c|}{168} & \multicolumn{2}{|c|}{84} & \multicolumn{2}{|c|}{639} \\
\hline Weight (kg) & 76 & 10 & 80 & 12 & 82 & 12 & 77 & 11 & 80 & 12 \\
\hline Height (cm) & 181 & 7 & 178 & 7 & 174 & 6 & 171 & 7 & 176 & 8 \\
\hline \multicolumn{11}{|l|}{ Energy intake } \\
\hline $\mathrm{kcal} / \mathrm{d}$ & 3180 & 736 & 2991 & 860 & 2749 & 665 & 2570 & 549 & 2895 & 782 \\
\hline $\mathrm{kJ} / \mathrm{d}$ & 13305 & 3079 & 12514 & 3598 & 11502 & 2782 & 10753 & 2297 & 12113 & 3272 \\
\hline Median & \multirow{2}{*}{\multicolumn{2}{|c|}{3124}} & \multirow{3}{*}{\multicolumn{2}{|c|}{2879}} & & & & & \multirow{2}{*}{\multicolumn{2}{|c|}{2806}} \\
\hline $\mathrm{kcal} / \mathrm{d}$ & & & & & \multicolumn{2}{|c|}{2692} & \multicolumn{2}{|c|}{2476} & & \\
\hline $\mathrm{kJ} / \mathrm{d}$ & \multirow{2}{*}{\multicolumn{2}{|c|}{13071}} & & & \multirow{2}{*}{\multicolumn{2}{|c|}{11263}} & \multirow{2}{*}{\multicolumn{2}{|c|}{10360}} & \multicolumn{2}{|c|}{11740} \\
\hline Water intake & & & & & & & & & & \\
\hline Beverages $(\mathrm{ml} / \mathrm{d})$ & 1535 & 632 & 1618 & 655 & 1485 & 601 & 1267 & 455 & 1526 & 620 \\
\hline Median & \multicolumn{2}{|c|}{1391} & \multicolumn{2}{|c|}{1497} & \multicolumn{2}{|c|}{1396} & \multicolumn{2}{|c|}{1182} & & \\
\hline Food water $(\mathrm{ml} / \mathrm{d})$ & 709 & 287 & 688 & 319 & 728 & 295 & 757 & 241 & 710 & 300 \\
\hline Metabolic water $(\mathrm{ml} / \mathrm{d})^{\star}$ & 386 & 90 & 363 & 105 & 333 & 83 & 310 & 67 & 351 & 96 \\
\hline Total water intake $(\mathrm{ml} / \mathrm{d})$ & 2630 & 754 & 2669 & 765 & 2546 & 668 & 2334 & 538 & 2588 & 720 \\
\hline Median & & & & & & & & & & \\
\hline Total water/energy (ml/kcal) & 0.83 & 0.17 & 0.91 & 0.23 & 0.94 & 0.22 & 0.92 & 0.19 & 0.91 & 0.22 \\
\hline Water excretion & & & & & & & & & & \\
\hline Non-renal water loss $(\mathrm{ml} / \mathrm{d})$ & 1342 & 723 & 1224 & 838 & 891 & 759 & 673 & 585 & 1079 & 805 \\
\hline Urine volume $(\mathrm{ml} / \mathrm{d})$ & 1288 & 571 & 1444 & 580 & 1655 & 627 & 1661 & 487 & 1509 & 594 \\
\hline Obligatory urine volume $(\mathrm{ml} / \mathrm{d})$ & 1110 & 378 & 1182 & 365 & 1411 & 418 & 1408 & 322 & 1263 & 394 \\
\hline $\mathrm{FWR}(\mathrm{ml} / \mathrm{d})$ & 178 & 487 & 263 & 514 & 244 & 583 & 253 & 528 & 246 & 531 \\
\hline FWR 3rd percentile (ml/d) & & & & & & & & & & \\
\hline Single value & & & & & & & & & & \\
\hline FWR $<0(\mathrm{ml} / \mathrm{d})$ & & & & & & & & & & \\
\hline Single value (\%) & & & & & & & & & & \\
\hline $\begin{array}{l}\text { Urine solutes }(\mathrm{mOsm} / \mathrm{d}) \\
\text { Urine solutes/enerav }(\mathrm{mOsm} / \mathrm{kcal})\end{array}$ & $\begin{array}{l}915 \\
0.30\end{array}$ & $\begin{array}{l}313 \\
0 \cdot 11\end{array}$ & 918 & 283 & $\begin{array}{l}992 \\
0.38\end{array}$ & $\begin{array}{r}294 \\
0.14\end{array}$ & 928 & $\begin{array}{l}212 \\
0 \cdot 10\end{array}$ & $\begin{array}{r}939 \\
0.34\end{array}$ & 283 \\
\hline Urine osmolality $(\mathrm{mOsm} / \mathrm{kg})$ & 775 & 238 & 697 & 221 & 652 & 210 & 601 & 196 & 682 & 222 \\
\hline Al of total water $(\mathrm{ml} / \mathrm{d})$ & & & & & & & & & & \\
\hline Single value & & & & & & & & & & \\
\hline Al total water/energy (ml/kcal) & & & & & & & & & & \\
\hline Single value & & & & & & & & & & \\
\hline $\begin{array}{l}\text { Decrease of urine solutes (mOsm/d) } \\
\text { Single value }\end{array}$ & & & & & & & & & & \\
\hline
\end{tabular}

FWR, free-water-reserve; Al, adequate intake.

* Metabolic water $(\mathrm{ml})=0.41 \times$ protein intake $(\mathrm{g})+0.55 \times$ carbohydrate intake $(\mathrm{g})+1.07 \times$ fat intake $(\mathrm{g})+1.17 \times$ alcohol intake $(\mathrm{g})$. 
Table 2. Anthropometric data, energy intake and results of water balance of women from a formerly representative sample of the German population (VERA study) (Mean values and standard deviations and medians)

\begin{tabular}{|c|c|c|c|c|c|c|c|c|c|c|}
\hline \multirow[b]{2}{*}{ Age (years) } & \multicolumn{2}{|c|}{$18-24$} & \multicolumn{2}{|c|}{$25-49$} & \multicolumn{2}{|c|}{$50-64$} & \multicolumn{2}{|c|}{$\geq 65$} & \multicolumn{2}{|c|}{ All } \\
\hline & Mean & SD & Mean & SD & Mean & SD & Mean & SD & Mean & SD \\
\hline$n$ & \multicolumn{2}{|c|}{101} & \multicolumn{2}{|c|}{468} & \multicolumn{2}{|c|}{225} & \multicolumn{2}{|c|}{95} & \multicolumn{2}{|c|}{889} \\
\hline Weight (kg) & 61 & 9 & 65 & 12 & 69 & 12 & 68 & 11 & 66 & 12 \\
\hline Height $(\mathrm{cm})$ & 167 & 6 & 165 & 6 & 161 & 6 & 159 & 6 & 164 & 7 \\
\hline \multicolumn{11}{|l|}{ Energy intake } \\
\hline $\mathrm{kcal} / \mathrm{d}$ & 2271 & 560 & 2174 & 627 & 2165 & 557 & 2072 & 483 & 2172 & 589 \\
\hline $\mathrm{kJ} / \mathrm{d}$ & 9502 & 2343 & 9096 & 2623 & 9058 & 2330 & 8669 & 2021 & 9088 & 2464 \\
\hline Median & & & \multirow{2}{*}{\multicolumn{2}{|c|}{2146}} & & & & & \multirow{2}{*}{\multicolumn{2}{|c|}{2149}} \\
\hline kcal & \multicolumn{2}{|c|}{2260} & & & \multicolumn{2}{|c|}{2165} & \multicolumn{2}{|c|}{2006} & & \\
\hline $\mathrm{kJ}$ & \multirow{2}{*}{\multicolumn{2}{|c|}{9456}} & \multicolumn{2}{|c|}{8979} & \multirow{2}{*}{\multicolumn{2}{|c|}{9058}} & \multicolumn{2}{|c|}{8393} & \multicolumn{2}{|c|}{8991} \\
\hline \multicolumn{7}{|l|}{ Water intake } & & & & \\
\hline Beverages $(\mathrm{ml} / \mathrm{d})$ & 1145 & 426 & 1249 & 524 & 1210 & 445 & 1130 & 409 & 1214 & 484 \\
\hline Meidan & \multicolumn{2}{|c|}{$1058^{4<0}$} & \multicolumn{2}{|c|}{1190} & \multicolumn{2}{|c|}{$1143^{445}$} & & & & \\
\hline Food water $(\mathrm{ml} / \mathrm{d})$ & 529 & 217 & 607 & 221 & 740 & 234 & 724 & 223 & 645 & 235 \\
\hline Metabolic water $(\mathrm{ml} / \mathrm{d})^{*}$ & 275 & 68 & 262 & 76 & 259 & 67 & 248 & 58 & 261 & 72 \\
\hline Total water intake $(\mathrm{ml} / \mathrm{d})$ & 1948 & 483 & 2118 & 622 & 2210 & 545 & 2102 & 516 & 2120 & 582 \\
\hline Median & & & & & & & & & & \\
\hline Total water/energy (ml/kcal) & 0.89 & 0.24 & 1.02 & 0.31 & 1.06 & 0.31 & 1.04 & 0.25 & 1.02 & 0.30 \\
\hline Water excretion & & & & & & & & & & \\
\hline Non-renal water loss $(\mathrm{ml} / \mathrm{d})$ & 712 & 577 & 694 & 645 & 612 & 586 & 551 & 612 & 660 & 621 \\
\hline Urine volume $(\mathrm{ml} / \mathrm{d})$ & 1237 & 656 & 1423 & 610 & 1598 & 568 & 1551 & 556 & 1460 & 609 \\
\hline Obligatory urine volume $(\mathrm{ml} / \mathrm{d})$ & 813 & 290 & 977 & 323 & 1111 & 279 & 1105 & 309 & 1006 & 324 \\
\hline $\mathrm{FWR}(\mathrm{ml} / \mathrm{d})$ & 423 & 583 & 446 & 532 & 487 & 468 & 447 & 505 & 454 & 520 \\
\hline FWR 3rd percentile $(\mathrm{ml} / \mathrm{d})$ & & & & & & & & & & \\
\hline Single value & & & & & & & & & & \\
\hline $\mathrm{FWR}<0 \mathrm{ml} / \mathrm{d}$ & & & & & & & & & & \\
\hline Single value (\%) & & & & & & & & & & \\
\hline Urine solutes $(\mathrm{mOsm} / \mathrm{d})$ & 669 & 239 & 754 & 243 & 781 & 212 & 731 & 204 & 749 & 233 \\
\hline Urine solutes/energy (mOsm/kcal) & 0.30 & 0.11 & 0.38 & 0.17 & 0.39 & 0.15 & 0.37 & 0.14 & 0.37 & 0.16 \\
\hline Urine osmolality (mOsm/kg) & 619 & 224 & 589 & 207 & 530 & 166 & 507 & 153 & 569 & 197 \\
\hline $\begin{array}{l}\text { Al of total water }(\mathrm{ml} / \mathrm{d}) \\
\text { Single value }\end{array}$ & & & & & & & & & & \\
\hline $\begin{array}{l}\text { Single value } \\
\text { Al total water/energy }(\mathrm{ml} / \mathrm{kcal})\end{array}$ & & & & & & & & & & \\
\hline Single value & & & & & & & & & & \\
\hline Decrease of urine solutes $(\mathrm{mOsm} / \mathrm{d})$ & & & & & & & & & & \\
\hline Single value & & & & & & & & & & \\
\hline
\end{tabular}

FWR, free-water-reserve; Al, adequate intake.

* Metabolic water $(\mathrm{ml})=0.41 \times$ protein intake $(\mathrm{g})+0.55 \times$ carbohydrate intake $(\mathrm{g})+1.07 \times$ fat intake $(\mathrm{g})+1.17 \times$ alcohol intake $(\mathrm{g})$. 
slightly increased with age in both sexes. Concomitantly, an age-related increase in urine volume and a decrease of urine osmolality occurred.

In Table 4, the hydration status of German men and women is compared after adjusting the different parameters for the sex differences in energy intake (by multiplying the female parameters of hydration status with the age-group-specific male-to-female energy ratio). The more unfavourable hydration status of men, indicated by a lower free-waterreserve of $359 \mathrm{ml} / \mathrm{d}$ (Table 4), originated from a reduced total water intake of $238 \mathrm{ml} / \mathrm{d}$ and a male-specific higher NRWL (mainly sweat loss) of $199 \mathrm{ml} / \mathrm{d}$ which was partly compensated by a lower obligatory urine volume of $78 \mathrm{ml} / \mathrm{d}$. The male-specific NRWL were lowest in men $\geq 65$ years (Fig. 1).

\section{Discussion}

In the present study, the exceptional combination of dietary weighed records and concomitantly utilisable $24 \mathrm{~h}$ urine samples ( $n$ 1528) was used to estimate individual $24 \mathrm{~h}$ hydration status from young to old adulthood in a formerly representative population sample. These data were only available in the earlier, but not the most recent German food consumption survey. For the first time, age-related effects on hydration status and its complex determining factors could be evaluated, allowing us to draw a quite complete picture of the underlying physiological alterations and to derive a reliable basis for water intake recommendations.

Although ageing affected nearly all parameters of water metabolism, the hydration status itself - as sum of these parameters (water intake, metabolic water, NRWL, urine volume and obligatory urine volume) - did not change with age. Older men and women promoted water supply by the increased consumption of food with a high water and low energy content and counteracted it by an increased sodium intake ${ }^{(20)}$. Focusing on the side of water losses, the increased demand for obligatory urine volume by the age-related decrease of renal concentrating capacity is well known ${ }^{(10)}$. In males of our study, the age-related decrease in NRWL predominantly compensated the increase of obligatory urine volume; in females, this NRWL-decrease was less pronounced and did therefore only partly compensate increased obligatory urine volume. However, the remaining 'gap' of water requirements with increasing age in women was balanced by slightly increasing total water intakes - showing the remarkably precise regulation of an adequate hydration status throughout life.

Both overall and maximum sweating rates decreased with age and this was greater in males than females ${ }^{(11,12)}$. As a general physiological concept, it can be assumed that the difference of NRWL in men and women is the sum of a basic energy-related part and a male-specific part (see Methods hydration status). In our study, the male-specific NRWL was remarkably lower in men above 50 years of age $(114 \mathrm{ml} / \mathrm{d})$ than in men younger than 50 years (about $270 \mathrm{ml} / \mathrm{d}$, Table 4). In men $\geq 65$ years old, energy-adjusted NRWL even fell below the values for women, resulting in negative male-specific NRWL of $-10 \mathrm{ml} / \mathrm{d}$. The well-known sex differences in sweating rates between men and women ${ }^{(21)}$ that do not occur until puberty $^{(22)}$ lead to the suggestion that androgen activity may be one important factor involved in the change of the male-specific NRWL coinciding with adrenarche and declining in the elderly. Several authors concluded that male hormones (e.g. testosterone) enhance the sweat response and female hormones (e.g. oestradiol) inhibit it ${ }^{(23,24)}$. Immunohistochemical studies that detected expression of androgen receptors in eccrine sweat gland cells in adults support this hypothesis $^{(25,26)}$.

Mean $24 \mathrm{~h}$ urine osmolality, an indirect parameter of hydration status, was $682 \mathrm{mOsm} / \mathrm{kg}$ in men and $569 \mathrm{mOsm} / \mathrm{kg}$ in women. Mean osmolalities in spontaneous urine samples of two representative groups in Germany and the USA showed comparable levels ${ }^{(27,28)}$. Overall, however, mean urine osmolalities from small groups of healthy subjects

Table 3. Effect of age $(\beta)$ on different parameters of water metabolism in the VERA study population

\begin{tabular}{|c|c|c|c|c|c|c|c|c|}
\hline & \multicolumn{4}{|c|}{$\operatorname{Men}(n 637)^{\star}$} & \multicolumn{4}{|c|}{ Women $(n 884)^{\star}$} \\
\hline & $\beta$ & SE & $R^{2}$ & $P \dagger$ & $\beta$ & SE & $R^{2}$ & $P \dagger$ \\
\hline Weight (kg) & 0.06 & 0.03 & 0.01 & 0.07 & 0.16 & 0.03 & 0.05 & $<0.0001$ \\
\hline Height $(\mathrm{cm})$ & -0.20 & 0.02 & 0.24 & $<0.0001$ & -0.17 & 0.01 & 0.18 & $<0.0001$ \\
\hline \multicolumn{9}{|l|}{ Water intake } \\
\hline Beverages $(\mathrm{ml} / \mathrm{d})$ & -1.67 & 1.41 & 0.18 & 0.24 & -0.97 & 1.05 & 0.04 & 0.36 \\
\hline Food water $(\mathrm{ml} / \mathrm{d})$ & 3.58 & 0.66 & 0.22 & $<0.0001$ & 4.78 & 0.44 & 0.30 & $<0.0001$ \\
\hline Metabolic water $(\mathrm{ml} / \mathrm{d}) \ddagger$ & -0.02 & 0.02 & 0.99 & 0.33 & -0.05 & 0.01 & 0.99 & $<0.0001$ \\
\hline Total water intake $(\mathrm{ml} / \mathrm{d})$ & 1.89 & $1 \cdot 32$ & 0.46 & 0.15 & 3.76 & $1 \cdot 13$ & 0.23 & 0.001 \\
\hline \multicolumn{9}{|l|}{ Water excretion } \\
\hline Non-renal water loss $(\mathrm{ml} / \mathrm{d})$ & $-7 \cdot 12$ & 1.61 & 0.35 & $<0.0001$ & $-3 \cdot 12$ & 1.25 & 0.18 & 0.01 \\
\hline Urine volume $(\mathrm{ml} / \mathrm{d})$ & 9.01 & 1.45 & 0.06 & $<0.0001$ & 6.88 & $1 \cdot 33$ & 0.03 & $<0.0001$ \\
\hline Obligatory urine volume $(\mathrm{ml} / \mathrm{d})$ & $8 \cdot 23$ & 0.92 & 0.13 & $<0.0001$ & $6 \cdot 67$ & 0.68 & 0.12 & $<0.0001$ \\
\hline Free-water-reserve $(\mathrm{ml} / \mathrm{d})$ & 0.78 & 1.33 & 0.02 & 0.56 & 0.22 & $1 \cdot 15$ & 0.003 & 0.85 \\
\hline Urine solutes (mOsm/d) & 1.82 & 0.69 & 0.05 & 0.009 & 1.64 & 0.51 & 0.04 & 0.001 \\
\hline Urine osmolality $(\mathrm{mOsm} / \mathrm{kg})$ & -2.99 & 0.54 & 0.06 & $<0.0001$ & $-2 \cdot 35$ & 0.43 & 0.04 & $<0.0001$ \\
\hline
\end{tabular}

* For two men and five women, no physical activity record was available.

$†$ Results of the linear regression model with age (in years) as independent continuous variable, adjusted for energy intake and physical activity. $\ddagger$ Metabolic water $(\mathrm{ml})=0.41 \times$ protein intake $(\mathrm{g})+0.55 \times$ carbohydrate intake $(\mathrm{g})+1.07 \times$ fat intake $(\mathrm{g})+1.17 \times$ alcohol $(\mathrm{g})$. 

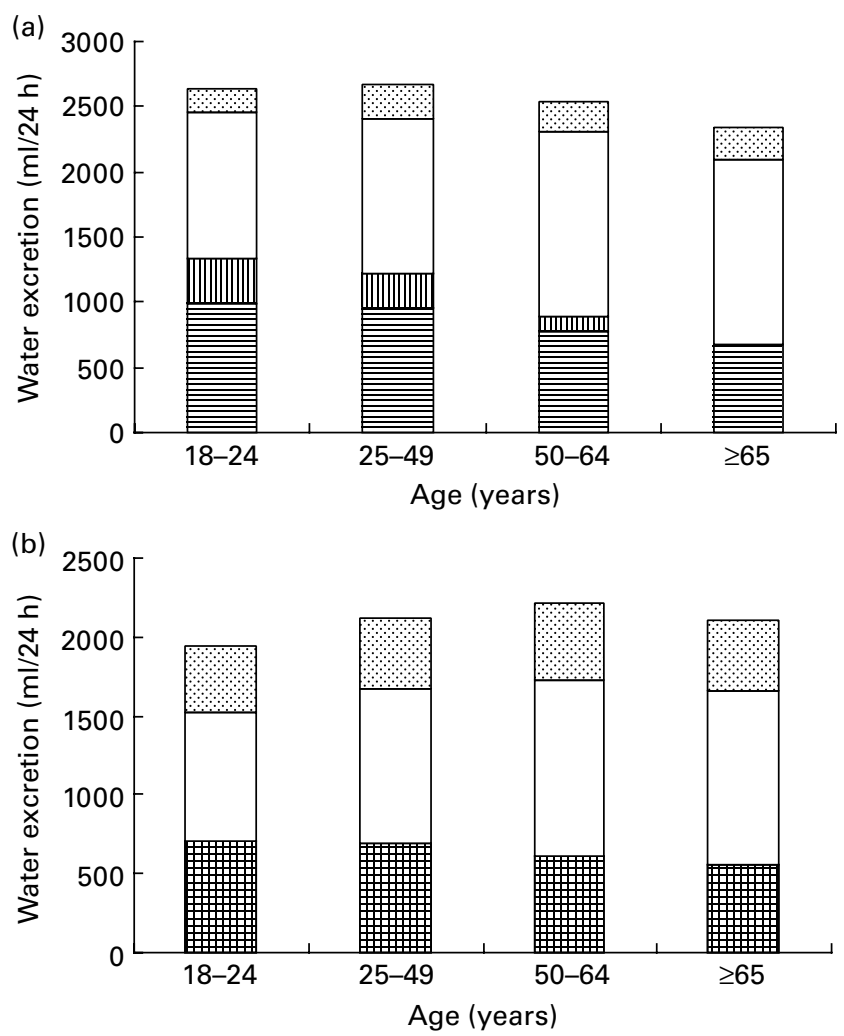

Fig. 1. Comparison of parameters of water excretion between (a) men and (b) women ( $n$ 1528), categorised according to age. Water excretion in urine: [.], free-water-reserve; $\square$, obligatory volume. Non-renal water loss: $\square$, male specific; 目, energy related; 团, total.

from all over the world were surprisingly widely scattered, indicating the large intercultural differences of urine osmolality and hinting at remarkable differences in the hydration status of different societies. Mean urine osmolality ranged from $909 \mathrm{mOsm} / \mathrm{kg}$ (China, 50-year-old adults ${ }^{(29)}$ ), across $536 \mathrm{mOsm} / \mathrm{kg}$ (UK, adults with a mean age of 44 years $^{(30)}$ ) to $392 \mathrm{mOsm} / \mathrm{kg}$ (Poland, children aged 5-18 years $\left.^{(10)}\right)$. It is not possible to define a physiological or natural narrow urine osmolality range as it is always influenced by the cultural context and habitual food intake. Only after additionally considering $24 \mathrm{~h}$ urine volume, urine solute excretion and maximum urine osmolality, quantification of individual $24 \mathrm{~h}$ hydration status is possible.
One unexpected finding was the almost parallel agerelated decrease in the mean urine osmolality seen in our study (men $-3.0 \mathrm{mOsm} / \mathrm{kg}$ per year; women $-2.4 \mathrm{mOsm} / \mathrm{kg}$ per year) and observed in standardised renal concentration tests $(-3.4 \mathrm{mOsm} / \mathrm{kg} \text { per year })^{(10)}$ as well as in the USA $\left(-3.9 \mathrm{mOsm} / \mathrm{kg}\right.$ per year ${ }^{(28)}$. These consistent findings in different cultures hint at a hypothetical physiological homeostatic mechanism that might regulate ad libitum drinking behaviour ${ }^{(31)}$ to counterbalance the age-related decrease in renal concentration capacity. In consequence, the freewater-reserve remains constant.

The important feature of the presented concept of freewater-reserve and calculation of $\mathrm{AI}$ is that it is not only based on median total water intake and maximum concentration capacity of the kidneys, but considers individual $24 \mathrm{~h}$ hydration status and adds a safety margin to ensure adequate water intakes in nearly all (97\%) healthy persons of a population. This safety margin was defined by the 3 rd percentile of free-water-reserve. No negative effects have to be expected by the resulting water surplus in individuals with a more favourable hydration status as water balance is regulated with precision in a wide range of water needs and intakes ${ }^{(32)}$. The fact that to date only a few countries included water in their dietary recommendations, and most of them not even considered renal concentration capacity but only based their recommendations on observed intakes ${ }^{(8)}$, shows the need for research in more depth in this topic. The concept of free-water-reserve can serve as a suitable measure to derive specific water intake recommendations also outside Germany (considering the population-specific maximum renal concentration capacity).

According to the concept of free-water-reserve, $40 \%$ of men and $19 \%$ of women with a free-water-reserve below zero were at risk of hypohydration. These sex differences in hydration status are also common in other industrialised countries, where males usually show a higher urine osmolality than females ${ }^{(28,33)}$. Many biological and social differences such as higher physical activity and preference for food with a low water and high energy density (e.g. meat products, fast food) in men compared to women may be responsible for this phenomenon ${ }^{(34)}$. In the present study, the in-detail analysis of parameters of water metabolism revealed that the strikingly higher prevalence of negative free-water-reserve in

Table 4. Differences between mean male and mean female parameters of water metabolism after adjusting the values of women to the energy intake of men

\begin{tabular}{lrrrrr}
\hline Age (years) & $18-24$ & $25-49$ & $50-64$ & $\geq 65$ & All \\
\hline Beverages (ml/d) & -68 & -100 & -51 & -135 & -92 \\
Food water (ml/d) & -32 & -147 & -212 & -141 & -150 \\
Metabolic water (ml/d) & 1 & 3 & 4 & 2 & 3 \\
Total water intake (ml/d) & -98 & -245 & -260 & -273 & -238 \\
Male-specific non-renal water loss (ml/d) & 345 & 269 & 114 & -10 & 199 \\
Obligatory urine volume (ml/d) & -28 & -162 & 0 & 37 & -78 \\
Free-water-reserve (ml/d) & -414 & -351 & -374 & -301 & $-359^{*}$ \\
Total water losses (ml/d) & -99 & -245 & -260 & -273 & -238 \\
\end{tabular}

* The lower free-water-reserve of men of $359 \mathrm{ml} / \mathrm{d}(100 \%)$ originated from a reduced total water intake of $238 \mathrm{ml} / \mathrm{d}(66 \%)$ and a male-specific higher non-renal water loss of $199 \mathrm{ml} / \mathrm{d}(55 \%)$ partly compensated by a lower obligatory urine volume of $78 \mathrm{ml} / \mathrm{d}(22 \%)$. 
men was due to higher NRWL and lower total water intakes that were only partly compensated by a lower obligatory urine volume (Table 4).

In the investigated population, adequate total water intake would have been ensured if all men (women) drank two (one) additional cups of beverages per d. A corresponding decrease in the obligatory urine volume by a lower urinary excretion of solutes is no realistic option. In men (women), protein intake would have had to be reduced by $56(28) \mathrm{g} / \mathrm{d}$ or $\mathrm{NaCl}$ intake by $9.3(4.6) \mathrm{g} / \mathrm{d}$. If $\mathrm{AI}$ of total water is to be attained by an exclusive increase in beverage consumption, median beverage intake in this German men (women) should have been $1826(1354) \mathrm{ml} / \mathrm{d}$. This value is, at least in men, clearly higher than the current German recommendation $^{(6)}$ of about $1400 \mathrm{ml}$ - depending on age - for beverage intake. Current recommended total water intakes for older adults ( 51 to $<65$ and $\geq 65$ years: $2250 \mathrm{ml} / \mathrm{d}$, not sex-stratified) are nearly equivalent to the observed median total water intakes in the present study (2282 and $2126 \mathrm{ml} / \mathrm{d}$ for 50 to $<65$ and $\geq 65$ years, respectively). However, these intake levels were accompanied by a prevalence of 29 and $27 \%$ of the respective age group that was at risk of hypohydration (i.e. had a free-water-reserve $<0 \mathrm{ml} / \mathrm{d}$ ), indicating the need for a revision of the current German intake recommendations. Compared to the US recommendation of the Institute of Medicine of 3700 (2700) $\mathrm{ml}$ for men (women), our calculated AI are substantially lower, probably mainly due to the traditionally higher water intakes in the USA compared to Germany ${ }^{(35,36)}$. As US AI were only set on the observed median intake at which an adequate hydration was assumed (estimated by plasma osmolality), it cannot be excluded that also for the US population lower AI values would be sufficient.

The main limitation of our study is the fact that the data presented in this study were collected a considerable number of years ago, and therefore we cannot draw reasonable conclusions on the actual hydration status of the German population. However, the estimated values for an adequate total water intake should be independent of the time of data collection, as the corresponding results have been yielded with a physiologically based 'free-water-reserve and water balance' assessment tool. Furthermore, we could only estimate whole non-renal water losses and were not able to differentiate between stool water, insensible water loss by respiration and through the skin (i.e. perspiration or transepidermal diffusion) and sweat loss.

In this formerly representative German sample, younger and older adults showed a similar hydration status. Correspondingly, total water requirements did not increase with age, clearly indicating that there is no need for age-specific water intake recommendations for the elderly (in contrast to sex stratification which appears necessary). Nevertheless, the elderly run a higher risk of dehydration, partly because their perception of thirst seems to be impaired ${ }^{(37)}$ and a larger water volume is necessary to excrete a given renal solute $\operatorname{load}^{(10)}$. It can be assumed that the physiological mechanisms which were responsible for the age-independent and widely constant total water requirements observed in this German sample (i.e. compensation of decreased renal concentration capacity by decreased NRWL, especially in men) may represent a universal finding with transferability also to other populations.

\section{Acknowledgements}

The present examination was supported by the Ministry of Science and Research, North Rhine-Westphalia, Germany. F. M. designed the study and together with S. A. J. wrote the report; A. W. was involved with analysis and interpretation of the study; H. B. provided administrative and statistical support; T. R. was responsible for the urine analysis and contributed to data interpretation. All authors contributed to the final version of the report. None of the authors has any conflict of interest in regard to this study. The authors thank Professor W. Kübler and Dr K.-J. Moch, Giessen, for their basic contributions to the NVS and VERA studies and the permission to use the respective public use files.

\section{References}

1. Wang Z, Deurenberg P, Wang W, et al. (1999) Hydration of fat-free body mass: review and critique of a classic bodycomposition constant. Am J Clin Nutr 69, 833-841.

2. Manz F \& Wentz A (2005) The importance of good hydration for the prevention of chronic diseases. Nutr Rev 63, S2-S5.

3. Rolls BJ \& Phillips PA (1990) Aging and disturbances of thirst and fluid balance. Nutr Rev 48, 137-144.

4. Kenney WL \& Chiu P (2001) Influence of age on thirst and fluid intake. Med Sci Sports Exerc 33, 1524-1532.

5. Jequier E \& Constant F (2010) Water as an essential nutrient: the physiological basis of hydration. Eur J Clin Nutr 64 , 115-123.

6. Deutsche Gesellschaft für Ernährung (Hrsg.) (2008) Reference Values for Nutrient Intake (in German). Umschau Verlag: Frankfurt a. M

7. Institute of Medicine (2006) Dietary Reference Intakes: The Essential Guide to Nutrient Requirements. Washington, DC: National Academic Press.

8. European Food Safety Authority (2009) Scientific opinion of the Panel on Dietetic Products Nutrition and Allergies. Draft dietary reference values for water. EFSA J 2-49.

9. Manz F, Wentz A \& Sichert-Hellert W (2002) The most essential nutrient: defining the adequate intake of water. $J$ Pediatr 141, 587-592.

10. Manz F \& Wentz A (2003) 24-h hydration status: parameters, epidemiology and recommendations. Eur J Clin Nutr 57, Suppl. 2, S10-S18.

11. Kenney WL \& Hodgson JL (1987) Heat tolerance, thermoregulation and ageing. Sports Med 4, 446-456.

12. Torii M (1995) Maximal sweating rate in humans. J Hum Ergol (Tokyo) 24, 137-152.

13. Speitling A, Hüppe R, Kohlmeier M, et al. (1992) Methodological Handbook Nutrition Survey and Risk Factor Analysis. VERA-Schriftenreibe Band Ia. Niederkleen: Wissenschaftlicher Fachverlag Dr. Fleeck.

14. Kübler W, Baltzer H, Grimm R, et al. (1997) National Food Consumption Survey (NVS) and Cooperative Study: Nutrition Survey and Risk Factor Analysis (VERA). Synopsis and Perspectives. VERA-Schriftenreibe Band XIV a. Niederkleen: Wissenschaftlicher Fachverlag Dr. Fleeck.

15. Heseker H, Adolf T, Eberhardt W, et al. (1992) Lebensmittelund Nährstoffaufnabme Erwachsener in der Bundesrepublik. 
Deutschland (Food and Nutrient Intake in Adults in the Federal Republic of Germany). VERA-Schriftenreibe Band III. Niederkleen: Wissenschaftlicher Fachverlag Dr. Fleeck.

16. Schneider R, Eberhardt W, Heseker H, et al. (1992) Die VERA Stichprobe im Vergleich mit Volkszählung, Mikrozensus und anderen nationalen Erhebungen (The VERA Sample Compared with Census, Microcensus and Other National Studies). VERA-Schriftenreihe Band II. Niederkleen: Wissenschaftlicher Fachverlag Dr. Fleeck.

17. Adolf T (1994) Public Use File National Food Consumption Survey (NVS) and Cooperative Study: Nutrition Survey and Risk Factor Analysis (VERA). Gießen: Institut für Ernährungswissenschaften.

18. Remer T, Neubert A \& Maser-Gluth C (2002) Anthropometrybased reference values for 24-h urinary creatinine excretion during growth and their use in endocrine and nutritional research. Am J Clin Nutr 75, 561-569.

19. National Research Council (1989) Recommended Dietary Allowances, 10th ed. Washington, DC: National Academic Press.

20. Kohlmeier M, Thefeld W, Stelte W, et al. (1995) Versorgung Erwachsener mit Mineralstoffen und Spurenelementen in der Bundesrepublik Deutschland (Minerals and Trace elements supply in adults in the Federal Republic of Germany). VERA-Schriftenreihe Band $V$. Niederkleen: Wissenschaftlicher Fachverlag Dr. Fleeck.

21. Gagnon D, Jay O, Lemire B, et al. (2008) Sex-related differences in evaporative heat loss: the importance of metabolic heat production. Eur J Appl Physiol 104, 821-829.

22. Rees J \& Shuster S (1981) Pubertal induction of sweat gland activity. Clin Sci (Lond) 60, 689-692.

23. Ichinose-Kuwahara T, Inoue Y, Iseki Y, et al. (2010) Sex differences in the effects of physical training on sweat gland responses during a graded exercise. Exp Physiol 95, $1026-1032$.

24. Araki T, Toda Y, Matsushita K, et al. (1979) Age differences in sweating during muscular exercise. J Physiol Fitness Jpn 28, 239-248.

25. Choudhry R, Hodgins MB, Van der Kwast TH, et al. (1992) Localization of androgen receptors in human skin by immunohistochemistry: implications for the hormonal regulation of hair growth, sebaceous glands and sweat glands. $J$ Endocrinol 133, 467-475.

26. Pelletier G \& Ren L (2004) Localization of sex steroid receptors in human skin. Histol Histopathol 19, 629-636.

27. Singhof S \& Manz F (2001) Flüssigkeitsversorgung der Senioren im Deutschland (Water supply in seniors in Germany). Aktuel Ernaebr Med 102-106.

28. Kutz FW, Cook BT, Carter-Pokras OD, et al. (1992) Selected pesticide residues and metabolites in urine from a survey of the US general population. I Toxicol Environ Health 37, $277-291$

29. Zhang L, Huang X, Li X, et al. (1997) Alterations in renal function in patients with obstructive sleep apnea syndrome and effects of continuous positive airway pressure. Chin Med J (Engl) 110, 915-918.

30. Fogarty AJ (1971) The significance of sodium in renal stone formation. Br J Urol 43, 403-405.

31. Epstein A (1991) Thirst and salt intake: a personal review and some suggestions. In Thirst, pp. 481-501 [D Ramsay and D Booth, editors]. London: Springer.

32. Sawka MN, Cheuvront SN \& Carter R 3rd (2005) Human water needs. Nutr Rev 63, S30-S39.

33. Waters WE, Sussman M \& Asscher AW (1967) Community study of urinary $\mathrm{pH}$ and osmolality. Br J Prev Soc Med 21, $129-132$

34. Ebner A \& Manz F (2002) Sex difference of urinary osmolality in German children. Am J Nephrol 22, 352-355.

35. Manz F \& Wentz A (2005) Hydration status in the United States and Germany. Nutr Rev 63, S55-S62.

36. Popkin BM, D'Anci KE \& Rosenberg IH (2010) Water, hydration, and health. Nutr Rev 68, 439-458.

37. Rikkert M, Hoefnagels W \& Deurenberg P (1998) Age-related changes in body fluid compartments and the assessment of dehydration in old age. In Hydration and Aging, pp. 13-32 [M Arnaud, R Baumgartner, J Morley, I Rosenberg and S Toshikazu, editors]. New York, NY: Springer Publishing Company. 